\title{
SEPSIS IN A DOG WITH CHRONIC KIDNEY DISEASE SUBMITTED TO PERITONEAL DIALYSIS
}

\author{
Silvano Salgueiro Geraldes ${ }^{1}$ \\ José Francisco Antunes Ribeiro ${ }^{2}$ \\ André Nanny LeSueur Vieira ${ }^{3}$ \\ Laura Pereira Porto ${ }^{4}$ \\ Alessandra Melchert ${ }^{5}$ \\ Pasqual Barretti ${ }^{6}$ \\ Carlos Roberto Padovani ${ }^{7}$ \\ Priscylla Tatiana Chalfun Guimarães-Okamoto ${ }^{8}$
}

\begin{abstract}
This study aims to report the continuous ambulatory peritoneal dialysis (CAPD) in a chronic kidney disease (CKD) dog, not responsive to conservative therapy. The animal had high levels of urea, but after three cycles of dialysis, there were decreased levels of urea. Due to the advanced stage of chronic kidney disease, the animal died and the necropsy findings were consistent with sepsis. Further studies needed in Veterinary Medicine regarding the choice of catheters, indication and type of peritoneal dialysis in order to avoid complications and achieve better results.
\end{abstract}

Keywords: CKD, canine, contamination, peritoneum.

\section{SEPSE EM UM CÃO COM DOENÇA RENAL CRONICA SUBMETIDO À DIALISE PERITONEAL}

\section{RESUMO}

Este estudo tem como objetivo relatar a utilização da diálise peritoneal ambulatorial contínua (DPAC) em um cão com doença renal crônica (DRC), não responsivo à terapia conservadora. O animal tinha altos níveis de ureia, mas após três ciclos de diálise, teve diminuição dos níveis de ureia. Devido à fase avançada de doença renal crônica, o animal foi a óbito e os achados de necropsia foram consistentes com sepse. A prática de diálise peritoneal é pouco comum na prática clínica. São necessários mais estudos na Medicina Veterinária em relação à escolha de cateteres, indicação e tipo de diálise peritoneal, a fim de evitar complicações e obter melhores resultados.

Palavras-chave: DRC, canino, contaminação, peritônio.

\footnotetext{
${ }^{1}$ FMVZ-Botucatu-SP, UNESP.

${ }^{2}$ Residência - Clínica de Pequenos Animais. FMVZ-Botucatu-SP, UNESP.

${ }^{3}$ Residência - Clínica de Pequenos Animais. FMVZ-Botucatu-SP, UNESP. Contato principal para correspondência.

${ }^{4}$ Graduanda de Medicina Veterinária. FMVZ-Botucatu-SP, UNESP.

${ }^{5}$ Departamento de Clínica Veterinária. FMVZ-Botucatu-SP, UNESP.

${ }^{6}$ Prof. Adjunto de Nefrologia - Departamento de Clínica Médica. FMVZ-Botucatu-SP, UNESP.

${ }^{7}$ Prof. Titular de Bioestatística. Departamento de Biofísica, IBB-UNESP-Btu.

${ }^{8}$ Profa. Ass. Departamento de Clínica Veterinária de Pequenos Animais-Nefrologia de Pequenos. FMVZ-Botucatu-SP, UNESP.
} 


\section{SEPSIS EN UN PERRO CON ENFERMIDAD RENAL CRÓNICA SOMETIDO A DIÁLISIS PERITONEAL}

\section{RESUMEN}

Este estudio tiene como objetivo informar de la diálisis peritoneal ambulatoria continua (DPAC) en un perro con enfermedad renal crónica (ERC), que no responde a la terapia conservadora. El animal tenía altos niveles de urea, pero después de tres ciclos de diálisis, había disminuido los niveles de urea. Debido a la etapa avanzada de la enfermedad renal crónica, el animal murió, los resultados de la autopsia fueron consistentes con sepsis. Se necesitan más estudios en Medicina Veterinaria en relación a la elección de los catéteres, rápido y tipo de diálisis peritoneal para evitar complicaciones y obtener mejores resultados.

Palabras clave: ERC, canino, contaminación, peritoneo.

\section{INTRODUCTION}

Chronic kidney disease patients with signs of uremia, unresponsive to conservative therapy, and exhibiting high levels of serum as urea higher than $90 \mathrm{mg} / \mathrm{dl}$ or $8 \mathrm{mg} / \mathrm{dL}$ of serum creatinine, have indication for peritoneal dialysis (1) especially the continuous ambulatory peritoneal dialysis (CAPD), which is the most appropriate technique for veterinary patients suffering from chronic kidney disease (2). This method of dialysis consists to passing the fluid and solutes from peritoneal capillaries to the dialysate infused into the peritoneal cavity through the peritoneum, which acts as a semipermeable membrane (3).

The dialysate is a commercial solution or a prepared one by adding $30 \mathrm{ml}$ of $50 \%$ glucose in 1 liter of Lactate Ringer's, which originate a solution whose concentration is $1.5 \%$ (1). Conventional dialysis solutions contain glucose, lactate, sodium, potassium and calcium, in different concentrations. Lactate, bicarbonate, or a combination of them, are used to generate a neutral $\mathrm{pH}$ in the dialysate. Glucose is the most commonly used osmotic agent (4), however cause unwanted effects, such as hyperglycemia, hyperlipidemia, hyperinsulinemia and obesity. The degradation products of glucose have been associated with changes in peritoneal permeability and ultrafiltration failure (1). Absorption occurs via the peritoneal lymph vessels, which keep the oncotic effect longer than the base dextrose solutions (1). The transport of fluid and solutes across the peritoneal membrane obeys the basic principles of diffusion, absorption and ultrafiltration (5).

The purpose of dialysis therapy is to achieve levels of urea between 60 and $100 \mathrm{mg} / \mathrm{dL}$ and creatinine between 4 and $6 \mathrm{mg} / \mathrm{dL}$. For nephropathic patients, serum urea concentration lower than $70 \mathrm{mg} / \mathrm{dL}$ is ideal (1).

Peritoneal dialysis should be maintained until renal function is normalized, that is, enough to keep the patient without dialysis, which would be determined by urine output, blood urea and creatinine values, and improvement of clinical signs (3).

Although Peritoneal Dialysis is an effective therapeutic option, its practice is little widespread in clinical routine. Further studies in veterinary medicine are needed in order to avoid complications and get better results. Thus, this study aims to report the sepsis as a complication of the peritoneal dialysis in dogs with terminal stage of chronic kidney disease.

\section{CASE REPORT}

A male dog, mongrel, age 11, was treated at the Veterinary Hospital of the Faculty of Veterinary Medicine and Animal Science of UNESP, Botucatu, with apathy, disorexia, 
progressive weight loss, emesis, melena, polyuria and polydipsia for about 1 week. All other laboratory tests such as hemogram, liver profile, kidney profile, serum electrolytes, urinalysis, urine protein creatinine ratio, thoracic radiography and abdominal ultrasonography revealed, respectively: pancytopenia, characterized by normocytic normochromic anemia, thrombocytopenia and leukopenia; hypoalbuminaemia, azotemia, hyperphosphatemia, isosthenuria and proteinuria, opacification of the caudal lung fields with predominantly interstitial pattern; loss of definition of renal corticomedullary ratio. On the clinical signs and results of laboratory tests, the diagnosis was hemoparasitosis and chronic kidney disease.

Intravenous fluid started in order to correct dehydration, and also started antiemetic therapy, metoclopramide and ranitidine hydrochloride. At the end of the day, was prescribed omeprazole, doxycycline, cyproheptadine and maintained antiemetic therapy. In the following days it was held maintenance intravenous fluid therapy, in order to keep animal hydrated for the dispose of pre-renal azotemia, and collection of new tests, which revealed improvement of thrombocytopenia and leukopenia, in addition to the persistence of azotemia, and hyperphosphatemia, confirming the suspicion of chronic kidney disease. Conservative therapy was instituted, with ambulatory intravenous fluid, ferrous sulfate and fish oil, aluminum hydroxide, enalapril and renal therapeutic diet.

After 15 days, new blood samples and urine samples were collected according to guidelines established by the International Renal Interest Society for staging of chronic kidney disease. The anemia worsened, there was an improvement of thrombocytopenia, persistent azotemia, isosthenuria protein and urinary creatinine ratio equal to $2.0 \mathrm{mg} / \mathrm{dL}$. Given the unfavorable clinical evolution of animal, it was performed blood transfusion and placement of nasogastric esophageal tube, keeping the conservative therapy. The patient, however, showed to be unresponsive to intravenous fluid routine, with progressive worsening. Given the critical situation, we opted for the realization of continuous ambulatory peritoneal dialysis. The animal was then submitted to omentectomy for Tenckhoff catheter insertion $15 \mathrm{~F}(5,0 \mathrm{mmx} 420 \mathrm{~mm})$ (VET Medical).

The renal biochemical profile performed prior to dialysis showed clear worsening of azotemia, with the values of urea reached $900 \mathrm{mg} / \mathrm{dL}$ and creatinine $14.7 \mathrm{mg} / \mathrm{dL}$. All other laboratory tests such as complete blood count, blood gas analysis, serum electrolytes, lactate measurement, blood glucose, blood pressure and intra-abdominal pressure, resulted in, respectively: nonregenerative anemia (hematocrit $=16 \%$ ) and leukocytosis $(45,000 \mu \mathrm{l})$, metabolic acidosis with mild compensatory respiratory acidosis $(\mathrm{pH}=7,220,=$ BEecf $15 \mathrm{mmol} / \mathrm{L} \mathrm{HCO} 3=13.1 \mathrm{mmol} / \mathrm{L}, \mathrm{pCO} 2=32.0 \mathrm{mmHg}), 149 \mathrm{mEq} / \mathrm{L}$ of sodium and 4.3 $\mathrm{mmol} / \mathrm{L}$ potassium lactate $5.8 \mathrm{mmol} / \mathrm{l}$ glucose $100 \mathrm{mg} / \mathrm{dL}$, systolic blood pressure was 140 $\mathrm{mmHg}$, and intra-abdominal pressure of $15 \mathrm{~cm} \mathrm{H}_{2} \mathrm{O}$.

For the realization of continuous ambulatory peritoneal dialysis (CAPD) a commercial dialysis solution polyelectrolytic Solution for Peritoneal Dialysis - 1.5\% glucose (Fresenius Medical Care) heated to a temperature of $39^{\circ} \mathrm{C}$ was used. Instillation dialysate began into the abdominal cavity at a rate of $10 \mathrm{ml} / \mathrm{kg} / \mathrm{h}$, an infusion rate reduced to avoid cardiovascular complications. After 40 minutes, time spent of the dialysis solution in the abdominal cavity, its withdrawal was performed, so that infused contents were drained by gravity to a bag, located in the bed below the level of the patient. Thus the first dialysis cycle was concluded. During this first cycle, the following parameters were monitored: heart rate of $128 \mathrm{bpm}$, respiratory rate of $32 \mathrm{mpm}$, intra-abdominal pressure of $15 \mathrm{~cm} \mathrm{H}_{2} \mathrm{O}$, blood pressure of $100 \mathrm{mmHg}$ and urine output of $1 \mathrm{ml} / \mathrm{kg} / \mathrm{h}$.

Since the animal was stable after the first cycle, the second dialysis cycle was initiated with rate of infusion which was $20 \mathrm{ml} / \mathrm{kg} / \mathrm{h}$. The heart rate was measured $132 \mathrm{bpm}$, respiratory rate $32 \mathrm{mpm}$, intraabdominal pressure $18.5 \mathrm{~cm} \mathrm{H}_{2} \mathrm{O}$, arterial pressure $140 \mathrm{mmHg}$ and urinary 
output remained at $1 \mathrm{ml} / \mathrm{kg} / \mathrm{h}$. At the end of this cycle, new blood samples were picked up for reassessment of serum urea and creatinine, which were, respectively, $259 \mathrm{mg} / \mathrm{dL}$ and $6.9 \mathrm{mg} / \mathrm{dL}$.

Despite the intensive care, the patient presented with progressive clinical deterioration and destabilization of the macro and microdynamic parameters, with no response to emergency therapy instituted. Unfortunately, the patient progressed to death after cardiac arrest unresponsive to resuscitation, then being requested necropsy. Renal histopathological examination confirmed pyelonephritis and glomerulonephritis. The cause of death was septic shock.

\section{DISCUSSION AND CONCLUSION}

The conservative medical treatment aims to slow chronic kidney disease progression, prevent complications arising from the gradual loss of kidney function and treat comorbidities (6). It is based on nutritional support, correction of dehydration and metabolic disorders, as well as therapy for renal protection (7).

The benefits of the diet are attributed mainly to the low level of phosphorus and the high level of omega 3 and 6 (8). Hyperphosphatemia is a major cause of bone and mineral disorders in chronic kidney disease. The mechanisms of phosphorus homeostasis maintain normal levels until the last stage of chronic kidney disease, in which there is an increase of parathyroid hormone, leading to osteopathy, vessel calcification and cardiovascular disease. Thus, the initial control phosphorus levels can prevent the consequences of bone-metabolic disorders of chronic kidney disease and controlling secondary hyperparathyroidism, which occurs in the last stage of the disease (9). In dogs with severe renal disease, only the phosphorous restriction of dietary may be insufficient to prevent hyperphosphatemia, the use of ion chelators, such as aluminum hydroxide, calcium carbonate and calcium acetate in the initial dose in this case is indicated, 90 $\mathrm{mg} / \mathrm{kg} / \mathrm{day}$, subject to reassessment in accordance with phosphorus levels measured after 12 hours. These medications should be administered with meals or 2 hours after that (8).

Although the patient has received the conservative treatment according to the literature, there has been no improvement of his clinical condition and in the values of urea and creatinine, with a need to perform peritoneal dialysis. The dialysis modality chosen was continuous ambulatory, which is indicated for patients with chronic kidney disease, according to Cooper and Labato (1), and Lucena and Mannheimer (2). It establishes the peritoneal dialysis in this report when the values of urea and creatinine of the patient were, respectively, $900 \mathrm{mg} / \mathrm{dL}$ and $10.2 \mathrm{mg} / \mathrm{dL}$, which agrees with Cooper and Labato (1), which preconize dialysis in patients who have serum urea levels above $90 \mathrm{mg} / \mathrm{dl}$ or higher than $8 \mathrm{mg} / \mathrm{dL}$ creatinine.

The used dialysate was a commercial-based solution of glucose (1.5\%). According Bersenas (4), glucose is the most commonly used osmotic agent, but may cause unwanted effects, such as hyperglycemia, which was not observed in the present case, since the patient remained in the blood glucose $100 \mathrm{mg} / \mathrm{dL}$.

After the completion of 2 cycles, there has been significant reductions in serum urea and creatinine, but below the values described by Ross and Labato (10), which reported aim of dialysis, serum urea concentrations between 60 and $100 \mathrm{mg} / \mathrm{dL}$ creatinine and between 4 and 6 $\mathrm{mg} / \mathrm{dL}$.

According to Labato (3), peritoneal dialysis should be maintained until renal function is normalized, or is enough to keep the patient without dialysis, which can be determined by urine output, blood levels of urea and creatinine, and improved clinical sings. In this case, maintenance cycles of dialysis was not possible because the patient was very weak, progressing to death.

Continuous ambulatory peritoneal dialysis was efficient in reducing serum urea and creatinine in the present report, even with a limited number of cycles performed. Thus, we 
conclude that peritoneal dialysis should be performed as soon as possible, seeking the restoration of renal function and, consequently, improve the patient's condition.

\section{REFERENCES}

1. Cooper RL, Labato MA. Peritoneal dialysis in veterinary medicine. Vet Clin North Am Small Anim Pract. 2011;41:91-113.

2. Lucena AR, Mannheimer EG. Diálise Peritoneal. In: Rabelo RC, Crowe Jr DT. Fundamentos de terapia intensiva veterinária em pequenos animais: condutas no paciente crítico. Rio de Janeiro: LF Livros; 2005. p.611-8.

3. Labato MA. Peritoneal dialysis. In: Bartges J, Polzin DJ. Nephrology and urology of small animals. Wiley: Blackwell Ltda; 2011. p.293-305.

4. Bersenas A. Renal failure and peritoneal dialysis. In: Proceedings of the 790 Western Veterinary Conference; 2007; Las Vegas. Las Vegas; 2007.

5. Pecoits Filho R, Moraes TP. Diálise peritoneal. In: Riella MC. Princípios de nefrologia e distúrbios hidroeletrolíticos. Rio de Janeiro: Guanabara Koogan; 2010. p.1032-42.

6. Roudebush P, Polzin DJ, Adams LG, Towell TL, Forrester SD. An evidence-based review of therapies for canine chronic kidney disease. J Small Anim Pract. 2010;51(5):244-52.

7. Polzin DJ. 11 guidelines for conservatively treating chronic kidney disease [Internet]. Lenexa; 2012 [cited 2012 Aug 31]. Available from: http://veterinarymedicine.dvm360.com/vetmed/Medicine/ArticleStandard/Article/detail/47 8487

8. Chew DJ, DiBartola SP, Schenk P. Acute renal failure. In: Chew DJ, DiBartola SP, Schenk P. Canine and feline nephrology and urology. St. Louis: Elsevier Saunders; 2011. p.63-92.

9. Martin KJ, Gonzalez EA. Prevention and control of phosphate retention/hyperphosphatemia in CKD-MBD: what is normal,when to start, and how to treat? Clin J Am Soc Nephrol. 2011;6(2):440-6.

10. Ross LA, Labato MA. Diálise peritoneal. In: DiBartola SP. Anormalidades de fluidos, eletrolíticos e equilíbrio ácido-básico na clínica de pequenos animais. São Paulo: Roca; 2007. p.614-27. 